Slávka Démuthová*

DOI: $10.2478 /$ v10241-012-0032-4

\title{
Psychological characteristics of juvenile offenders with constant integration problems
}

\begin{abstract}
The aim of this study is to identify the typical psychological, demographic, socio-economical, educational, health, and criminological characteristics of juvenile delinquents who tend to continue in their criminal career to adulthood and therefore obstruct the possibility of successful, non-offending integration to society. Subjects of research were young male prisoners jailed in the Juvenile imprisonment house that completed the test battery. By ex-post analysis after a period of five years, the differences between offenders and non-offenders were identified. Results show significant differences in the age of prisoners, length of imprisonment, presence of violent offence (esp. robbery) in the criminal history, number of previous offences recorded, differences in factors $i, h$, and $q_{1}$ from the Sixteen Personality Factor Questionnaire, responses within the Hand test characteristic (affection, dependence, and communication), and in several signs of the drawings in a Draw-A-Person test. The importance and influence of listed factors is discussed.
\end{abstract}

KEYWORDS: juvenile delinquency, recidivist, non-recidivist, psychological characteristics

* Correspondence regarding the paper should be sent to: Slávka Démuthová, Department of Psychology, Faculty of Arts and Sciences, University of Ss. Cyril and Methodius in Trnava, Nám. J. Herdu 2, 91701 Trnava, Slovak Republic, e-mail: demuthovci@yahoo.com; slavka.demuthova@ucm.sk 


\section{INTRODUCTION}

Juvenile delinquency belongs to the serious problems of our societies. This negative phenomena can be an outcome of the problematic developmental period (puberty and adolescence - Tavel, 2012) when authorities and norms are being relativized (Siegel \& Senna, 1988). On the other hand, it can point to the beginning of lifetime criminality and chronic behavior that breaks the social norms. It seems it is a key problem to distinguish between so-called "adolescence limited" and "life-course-persistent" antisocial behavior (see e.g., Moffitt, 1993; Moffitt \& Caspi, 2001). The serious problems for the society represent those individuals who commit crime repeatedly. They make an economic burden (due to their repeated imprisonments) and they are a rising threat as well, because their criminality becomes usually more and more serious (in the number of offenses and in their severity, too). Recently, statistics show that in Slovakia around 30\% of imprisoned adults belong to the group of recidivists (Statistical yearbook 2011).

Forensic psychology during its history has made a great effort to identify the etiological components of criminality. There are dozens of theories stressing several risk factors leading towards behavior that breaks the law of certain legal systems. Usually, they are the outcome of researches made on adult offenders and they do not differentiate between the occasional and chronic criminality. Studies that concentrate on youngsters and track the criminal career for longer periods are occasional and very rare. There is no constant evidence of how many juvenile delinquents continue in their criminal career after release from the juvenile imprisonment house and become offenders also in their adulthood in Slovakia. Existing data is poor and not actual. During 1985 - 1990 the amount of recidivism within five years after release from the juvenile imprisonment house was between 60\% (1985) and 40\% (1989) (Lobodáš In Ondrejkovič, 2000). There are no studies focused on the characteristics of juvenile delinquents that 
become chronic offenders in their lives, even though this might be valuable information not only for the handling of penitentiary treatment, but also for all stages of intervention.

\section{AIMS OF RESEARCH}

The aim of this study is to identify the typical characteristics of juvenile delinquents who tend to continue in their criminal career to adulthood. The characteristic should contain various types of data from psychological, demographic, socio-economical, cultural, educational, health, and criminological areas to provide as complex view as possible.

\section{SUBJECTS AND METHODS}

The research has been conducted in two phases. The first phase was carried out in 2006 and all available male juvenile delinquents in the Juvenile imprisonment house have been recruited for an examination. Juvenile imprisonment house gathers all young men (aged 14 to 18) from the country, that have been sentenced to a term of imprisonment. If the mandatory sentence lasts even after the prisoner's 18th birthday, there is a possibility to keep this offender in the institution. As we aimed to test juveniles only, we followed the legal definition and excluded those who reached the age of 18 already. This was a great part of the jailed as the majority of offenders commits their crimes in the higher age (16 or 17) and there is some period from their felony till the placement in the imprisonment house caused by the processes of law enforcement proceedings. Therefore the majority of inmates are over eighteen. However, as there passed some time from the recruitment for the research and the finishing of testing, finally we had some 18-year olds in our sample. These were those who 
reached the age of 18 during the research. Further on, we had to exclude those who were not able to understand the language in its spoken way; analphabets $(\mathrm{N}=3)$ were kept in the sample. There were some subjects excluded on the end of testing as they did not attend (for a variety of reasons) all testing sessions. On the end we ended up with 58 prisoners aged from 16 to 18 which makes approximately one third of the number of all juvenile delinquents sentenced to a term of imprisonment per year.

Police records and records from social workers were used for gathering demographic, socio-economical, cultural, educational, health, and criminological data about the subjects. We have verified and completed this information by administration the short questionnaire which was filled in by each subject. For a description of the personality we have used The Sixteen Personality Factor Questionnaire (16 PF) by Eber \& Cattell adapted by Kollarik (1994) for the individuals with limited education and problematic cultural background. This version (E) has been standardized to the Slovak population and consists of all 16 of Cattell's personality factors. For measurement of intelligence we used the Raven Test of Progressive Matrices (Raven, Court, \& Raven, 1991) and Army Beta Test. For conversion of the gross score to the IQ score we used the conversions by Bakalár (1993).

We also used a Wagner's projective Hand Test (Slovak standardization made by Fridrich \& Nociar, 1991) and the Test of Unfinished Sentences mapping subjects' relationship to 13 areas: relationship to mother, father, and family, friends, to subject's own abilities, school, to the past, to the offense, to the rules and the law, feelings of guilt, anxieties and fears, goals, and plans for the future. All completions of unfinished sentences were evaluated and divided into groups according to their contents. The last projective method was the Draw-a-Person-Test (DAP) with the instruction to draw a person and afterwards the opposite sex figure. Each part of the figure has been evaluated by quality separately for each figure. The order, size, and position of fig- 
ures together with organic and aggressive tendencies have been monitored, too. Qualitative analysis has been executed according to guidelines published in Altman (1998); Šturma \& Vágnerová (1982); Dammer (1995), and Davido (2001).

The second phase started in 2011, five years after the examination. Five year's period is commonly used as the critical period for recidivism (see. e.g., Hanson \& Wallace-Carpretta, 2004; Lobodáš In Ondrejkovič, 2000). Research lasted till July 2012 and the criminal records of subjects examined in 2006 were checked. Research subjects of the second phase were those males from the 2006-year's sample who relapsed in their offending and they have been sentenced again $(\mathrm{N}=19)$. In order to highlight the specifics of the group of recidivists, we compared their characteristics with those males from the 2006-year's sample who did not re-offend even after a period of five years $(\mathrm{N}=23)$ to show the characteristics important for identification of chronic delinquents. Chi-square analyses of categorical variables and t-tests with U-tests of continuous variables were conducted within the SPSS program, version 16 .

\section{RESULTS AND INTERPRETATIONS}

We used the SPSS program to test whether the differences in characteristics of two groups (recidivists and non-recidivists) are significant. For categorical variables with normal distribution (in the Shapiro-Wilk $W$ test $p \geq .005$ ) the independent samples t-tests were used. For continuous variables which did not have the normal distribution (in the Shapiro-Wilk $W$ test $p \leq .005$ ) the non-parametric Mann-Whitney U-tests were used. Categorical variables were examined by Chi-square analyses.

Significant $(\mathrm{p} \leq .05)$ differences between the group of recidivists and non-recidivists detected by t-test presents table 1 . 
Table 1. Significant differences between group of recidivists and group of nonrecidivists (t-test) in selected variables

\begin{tabular}{|l|c|c|c|c|c|c|c|c|}
\hline \multirow{2}{*}{} & \multicolumn{3}{|c|}{ recidivists } & \multicolumn{3}{c|}{ non-recidivists } & \multicolumn{2}{c|}{ t-test values } \\
\cline { 2 - 10 } & $\mathrm{N}$ & Mean & SD & N & Mean & SD & t & sig. \\
\hline age & 19 & 16,44 & .727 & 23 & 17,24 & .486 & 4,121 & .000 \\
\hline factor h (16 PF) & 19 & 4,26 & 1,628 & 23 & 5,39 & 1,53 & 2,297 & .027 \\
\hline $\begin{array}{l}\text { AFF+DEP+COM } \\
\text { (Hand Test) }\end{array}$ & 19 & 12,26 & 3,942 & 23 & 8,87 & 3,609 & $-2,884$ & .006 \\
\hline
\end{tabular}

Group of recidivists consisted of younger delinquents as the group of non-recidivists. The age difference corresponds with theories orientating towards the specifics of career of the offender. The earlier problems in behavior, contacts with the police, first offenses, arrests, etc. occur in life, the bigger is the chance that they will continue all life through and their severity and frequency will grow (see e.g., Moffitt, 1993; Moffitt \& Caspi, 2001). Recidivists were also significantly more socially bold, venturesome, thickskinned, uninhibited (factor h of The Sixteen Personality Factor Questionnaire) than non-recidivists. The value of factor $h$ in the group of recidivists has been not only higher than in the group of non-recidivists, but differed $(\mathrm{df}=1,14)$ also from the average (mean=3,12; SD=1,79) stated in the manual for the normal population (Eber \& Cattell adapted by Kollarik, 1994). Surprisingly, the value of $\mathrm{AFF}+\mathrm{DEP}+\mathrm{COM}$ (from the Hand Test) was higher in recidivists than in non-recidivists. $\mathrm{AFF}+\mathrm{DEP}+\mathrm{COM}$ value is counted as a part of Acting-out ratio (AOR), which is one of the most important predictors of the Hand Test. AOR predicts the occurrence of aggressive behavior. It is based on the ratio of positive cooperative attitudes against aggressive $(\mathrm{AOR}=[\mathrm{AFF}+\mathrm{DEP}+$ COM]:[DIR + AGG]). The more the sum of DIR + AGG answers exceeds the sum of the AFF + COM + DEP responses, the higher is the probability of occurrence of antisocial and aggressive behavior (Fridrich \& Nociar, 1991). Table 1 shows, that in the group 
of recidivists the answers presenting a positive and cooperative attitude were more frequent than in the group of non-recidivists. Possible explanation is, that those criminals who have the ability to apply positive ways of communication rather than negative, have a better chance to affect their victims and therefore subsequently also better chances for crime.

Table 2. Significant differences between a group of recidivists and a group of non-recidivists (U-test) in selected variables

\begin{tabular}{|l|c|c|c|c|c|c|c|c|}
\hline & \multicolumn{3}{|c|}{ recidivists $(\mathrm{N}=19)$} & \multicolumn{3}{c|}{ non-recidivists $(\mathrm{N}=23)$} & \multicolumn{2}{|c|}{ U-test values } \\
\cline { 2 - 10 } & Mean & $\begin{array}{c}\text { Mean } \\
\text { Rank }\end{array}$ & $\begin{array}{c}\text { Sum of } \\
\text { Ranks }\end{array}$ & Mean & $\begin{array}{c}\text { Mean } \\
\text { Rank }\end{array}$ & $\begin{array}{c}\text { Sum of } \\
\text { Ranks }\end{array}$ & U & sig. \\
\hline punishment & 30,89 & 30,66 & 582,5 & 12,22 & 13,93 & 320,50 & 44,5 & .000 \\
\hline prior offenses & .58 & 17,74 & 337,0 & .91 & 24,61 & 566,00 & 147,0 & .046 \\
\hline factor i $(16 \mathrm{PF})$ & 4,32 & 25,71 & 488,5 & 3,43 & 18,02 & 414,5 & 138,5 & .039 \\
\hline factor $\mathrm{q}_{1}(16 \mathrm{PF})$ & 4,16 & 25,79 & 490,0 & 3,17 & 17,96 & 413,0 & 137,0 & .033 \\
\hline $\begin{array}{l}\text { DEP } \\
\text { (Hand Test) }\end{array}$ & 1,00 & 27,53 & 523,0 & .09 & 16,52 & 380,0 & 104,0 & .000 \\
\hline $\begin{array}{l}\text { COM } \\
\text { (Hand Test) }\end{array}$ & 7,53 & 27,55 & 523,5 & 5,22 & 16,50 & 379,5 & 103,5 & .003 \\
\hline
\end{tabular}

Results of non-parametric Mann-Whitney U-test show that juvenile delinquents from the group of recidivists were sentenced with longer imprisonment than the delinquents from the group of non-recidivists. The length of imprisonment depends on the seriousness of the committed offence. Crimes committed by the group of recidivists were far more serious than those committed by non-recidivists - this fact is accentuated by the finding that non-recidivists were sentenced before their imprisonment more often than recidivists (mean value of prior offenses in the table 2 represents the number of prior offenses). Furthermore, $69,6 \%$ of non-recidivists were under probation when being sentenced (compared to $42,1 \%$ of recidivists) and sent to the imprisonment house 
for delinquents. According to Slovak law, the length of imprisonment of a person who commits an offence under probation results from the sum of two offences - prior and actual. In spite of this fact, the length of imprisonment in the group of non-recidivists was shorter than in the group of recidivists. Their offenses were so serious, that in spite of that they were mostly firstly sentenced, they were given significantly longer penalties. From this data two trajectories of criminal career can be seen. Non-recidivists start their criminal career later in life with minor offences leading to probation under which they commit another offence. Recidivists start to commit crimes earlier and usually they are so serious that they are sentenced with imprisonment.

Other significant differences can be seen in the factor $i$ and factor $\mathrm{q}_{1}$ of The Sixteen Personality Factor Questionnaire, which means that recidivists are more open to change, experimental, liberal, critical, free-thinking, flexible and less traditional, attached to familiar, conservative, respecting traditional ideas than nonrecidivists (factor q1). In this factor, recidivists scored higher than the normal population (mean $=2,71 ; \mathrm{SD}=1,53$ ) with the difference of 1,45 points (Eber \& Cattell adapted by Kollarik, 1994). According to the characteristics of the factor $i$ the group of recidivists scored higher also in sensitivity, sentiment, intuitiveness, seeking for compassion in terms of contraposition of such characteristic as utilitarian, objective, unsentimental, tough minded, self-reliant, and no-nonsense. In the factor $i$, the group of recidivists gained the difference of 1,49 points from the normal population (mean=2,83; $\mathrm{SD}=1,73$ ) (ibid.).

Consistent with the emotional dependence tendency manifested in the factor i, recidivists responded in the Hand Test more often with answers pointing to dependence (DEP) than non-recidivists. Another significantly higher (compared to nonrecidivists) frequency of answers in the Hand Test was the COM (communication) category. From the high frequency of the communication (COM) and dependence (DEP) answers it is obvious 
that the higher value of the sum of positive cooperative attitudes $(\mathrm{AFF}+\mathrm{DEP}+\mathrm{COM})$ was in the group of recidivists saturated by these two variables. The Affection (AFF) category was not so influential.

Table 3. Significant differences between group of recidivists and group of nonrecidivists (Chi-square) in selected variables

\begin{tabular}{|l|c|l|l|l|c|c|}
\hline \multirow{2}{*}{} & \multicolumn{2}{|c|}{ recidivists } & \multicolumn{2}{c|}{ non-recidivists } & \multicolumn{2}{c|}{$\begin{array}{c}\text { Pearson Chi- } \\
\text { square values }\end{array}$} \\
\cline { 2 - 7 } & $\mathrm{N}$ & \multicolumn{1}{|c|}{ categories } & $\mathrm{N}$ & \multicolumn{1}{|c|}{ categories } & $\mathrm{X}^{2}$ & sig. \\
\hline robbery & 19 & $\begin{array}{l}\text { yes (10) } \\
\text { no (9) }\end{array}$ & 23 & $\begin{array}{l}\text { yes (2) } \\
\text { no (21) }\end{array}$ & 9,842 & .002 \\
\hline violent crimes & 19 & $\begin{array}{l}\text { yes (13) } \\
\text { no (6) }\end{array}$ & 23 & $\begin{array}{l}\text { yes (5) } \\
\text { no (18) }\end{array}$ & 9,259 & .002 \\
\hline disproportions - A & 17 & $\begin{array}{l}\text { yes (2) } \\
\text { no (15) }\end{array}$ & 19 & $\begin{array}{l}\text { yes (10) } \\
\text { no (9) }\end{array}$ & 6,743 & .009 \\
\hline small head - A & 17 & no (17) & 19 & $\begin{array}{l}\text { yes (4) } \\
\text { no (15) }\end{array}$ & 4,026 & .045 \\
\hline exaggerated sexual hints - B & 17 & $\begin{array}{l}\text { yes (6) } \\
\text { no (11) }\end{array}$ & 18 & $\begin{array}{l}\text { yes (1) } \\
\text { no (17) }\end{array}$ & 4,833 & .028 \\
\hline relationship to mother - C & 19 & $\begin{array}{l}\text { positive (15) } \\
\text { neutral (3) } \\
\text { ambivalent (1) }\end{array}$ & 23 & $\begin{array}{l}\text { positive (10) } \\
\text { neutral (12) } \\
\text { ambivalent (1) }\end{array}$ & 6,074 & .048 \\
\hline
\end{tabular}

Note. A - signs of the self-identification drawing in the Draw-A-Person test $\mathrm{B}$ - signs of the opposite-sex drawing in the Draw-A-Person test $\mathrm{C}$ - from the test of Unfinished sentences

Significant differences between the group of recidivists and non-recidivists in categorical variables summarizes the table 3 . Severity of crimes committed by the group of recidivists underlines the difference in the number of violent crimes generally and in the number of committed robberies, too. The group of recidivists is therefore typical with violent acts which are punished with long-lasting imprisonment. 
In the Draw-A-Person test the group of recidivists scored significantly lower in the category of disproportions. The occurrence of disproportions in the self-identification drawing may point to the presence of organicity (Šturma \& Vágnerová, 1982) and subsequently to the lower intellect level of the group of nonrecidivists. From this criterion the higher intellect level of the recidivists might be outlined. Even though the differences in the levels of intellect between two groups were not significant, in both tests - Army Beta (mean=89,5; $\mathrm{SD}=17,51)$ as well as in the Raven Test of Progressive Matrices $(76,63, \mathrm{SD}=20,98)$ recidivists scored higher than non-recidivists. This is in accordance with the lower disproportion occurrence. Another differentiating variable in the Draw-A-Person test was the more frequent presence of the small head (in comparison with the rest of the body) in the group of recidivists. This sign of drawing points to low self-esteem especially in the area of cognitive abilities. Non-recidivists seem to be more critical in the area as they have significantly higher occurrence of this sign in the self-identification drawings as the group of recidivists (zero occurence). Exaggerated sexual hints in the opposite-sex drawing reveal inadequate relationships with people of the opposite sex. Women might be seen by recidivists more as primarily sexual objects.

Recidivists stated significantly better relationships to mother as non-recidivists. This may be an outcome of the disrupted family background where fathers usually either leave the family or act violently towards other members. As mothers tend to stay with children, anger and frustration is therefore orientated more towards fathers. This may lead to the tighter and more positive bonds to mother. The analysis of family background of recidivists showed, that the majority of subjects lived in the non-functional social background - in $63,2 \%(\mathrm{~N}=12)$ of families there were disrupted relationships reported. 


\section{DISCUSSION}

Interpretations of the results have their limitations in the size of the sample. The research started with the complete population of the juvenile (above the age of 14 and below the age of 18 years) delinquents, but it ended up with the group of 19 recidivists only. Even though the test for the normality of distribution of all observed variables has been executed and most of the variables were compared by more rigorous non-parametric tests, the size of the groups is not big enough to outline the generally valid statements. However, the research pointed to some important features of the group of offenders, who tend to continue in their criminal career from adolescence to adulthood.

Only a few of the typical features were connected with the personality of the recidivist. This fact is consistent with a list of findings, where there has not been found a universal profile of recidivist consisting of personality characteristics only. Existing older attempts and findings (e. g. Clark, 1948; Freeman \& Mason, 1952) have been reconsidered and only a few variables remained (e.g., psychopathy from MMPI, extroversion from EPI - Matoušek \& Krofrová, 1998).

Ex post analysis based on comparison of the group of recidivists and non-recidivists focused on complex characteristics measured at the time of imprisonment showed, that the recidivists from the research sample are more socially bold, venturesome, thick-skinned, uninhibited, open to change, experimental, liberal, critical, free-thinking, flexible and less traditional, attached to familiar, conservative, respecting traditional ideas than nonrecidivists. These characteristics are in accordance with studies stressing the characteristics of recidivists such as extroversion (Dam, Janssens, \& DeBruyn, 2005) or low warmth (Edens, 2009).

Recidivists also showed signs of exaggerated self-esteem mainly in the area of intellectual abilities which contradicts the facts (an average IQ in Army Beta Test was 89,5 and in Raven Test of 
Progressive Matrices 76,63). There are several studies focused on self-concept, self-esteem and self-confidence in delinquents, however, they bring different results. Lee \& Lee (2012) supported our findings with the outcomes that showed the linear growth in self-esteem and delinquency. On the other hand, some others bring opposite findings (e.g., Levy, 1997).

Results showed higher rates in variables connected with positive cooperative attitudes to others - recidivists scored higher in $\mathrm{AFF}+\mathrm{DEP}+\mathrm{COM}$ categories in the Hand Test than the group of non-recidivists. Presence of these positive characteristics together with the higher intelligence (recidivists scored non-significantly higher in intelligence tests than non-recidivists) enables them to get in better contacts with others and increases their possibilities for offending. The higher intelligence also enables them to answer in the tests in a socially desirable way. Other variables showed (factor $\mathrm{h}$ and $\mathrm{q} 1$ from $16 \mathrm{PF}$ ), that their interpersonal contacts are not as positive as seen from mentioned positive cooperative attitudes.

Recidivists showed (in the Draw-A-Person test) inappropriate relationships to the opposite sex. Juvenile age brings new developmental task demanding the creation of the relationship to the opposite sex with the need of incorporation of its new features (e.g., psychological and also sexual intimacy). Coping with this task is difficult and the delinquent subculture is prone to deviate to the problematic ways of handling such a delicate challenge. Being rough, emotionless, promiscuous and even violent is considered as a sign of maturity and such behavior is being valued and thus reinforced. Except the developmental aspect of the character of the inter-sexual relationships there is also a personality aspect present. Prior research conducted on the groups of offenders confirm the presence of the characteristics that complicate normal interpersonal relations - antisocial personalities are characteristic by high dominance and low warmth (Edens, 2009). 
Further distinctive characteristics between the group of recidivists and non-recidivists were connected with criminological data. Recidivists were not under probation when they have been arrested and sentenced for imprisonment. Therefore it seems that being sentenced prior in life and then being caught again and sent to prison works as a good deterrent. Being imprisoned with the only one court experience is not sufficient for preventing reoffending. This fact was stressed also by Carcach \& Leverett (1999) who found that supervised orders appear to have a positive effect in the recidivism of juveniles with 2 and 3 (not one) previous proven appearances.

Recidivists in our research group were jailed with longer sentences than non-recidivists. This was a result of the severity of the offence they have committed. The question is, how the longer imprisonment influences the formation of young adults and whether this is not the partial cause of their further social failure. Institutional care as well as life in the sole criminal surrounding are one of the most frequent arguments that are stressed when listing the disadvantages and risks of imprisonment (Coates, 1981; Matoušek \& Kroftová, 1998).

Several studies mention the age of the first offence as an important variable for further criminal career (e.g., Ganzer \& Sarason, 1973; Mulder, Brand, Bullens, \& van Marie, 2011). Research sample of recidivists was significantly younger than the group of non-recidivists. Offending in the young are together with the seriousness and violent character of committed offences point to signs of pathology commonly present in the personality of recidivists. Recidivists committed more violent offences (mainly robberies) than the group of non-recidivists. The fact that being a violent offender increases the probability of future offending puts another importance to the need of research. Violence present with offending represents a serious threat to the health and even life of a victim. 


\section{CONCLUSION}

The aim of the research was to compare several psychological, demographic, socio-economic, educational, health, and criminological characteristics of recidivists and non-recidivists and subsequently to identify distinctive characteristics typical for the group of juvenile recidivists. Research was conducted on the entire population of young delinquents imprisoned in the Juvenile Imprisonment House in Slovakia in 2006. After applying the age restriction for the definition of juvenile delinquents (above 14 and below 18), availability of the delinquents, and the condition of speaking and understanding the official language, only 58 prisoners were left. Five years later (in 2011) the criminal records of these subjects were checked. Nineteen of the former prisoners committed a crime again and were sentenced while 23 of the others did not have a criminal record even after a period of five years after the release from the imprisonment house. Based on the comparison of these two groups and from the statistically significant differences the typical features of recidivists were identified.

Former juvenile delinquents who tend to continue in their criminal career to adulthood are socially skilled and communicative. Within interpersonal contacts they are bold, experimental, liberal, but also emotionally dependent, intuitive, and seeking for compassion. Their disrupted family background disadvantages them in attempts for creating normal interpersonal bonds which are reflected e.g. in inappropriate relationships to the opposite sex (sexual objects, aggression) or tighter bonds to the mother. Recidivists are violent in their offences and they have committed their crimes early in life. They have exaggerated self-esteem, mainly in the area of intellectual abilities. Imprisonment is the outcome of their first (at most the second) court experience and is not sufficient enough for preventing re-offending. All these characteristics have to be interpreted within the limitations of this research. 


\section{REFERENCES}

Altman, Z. (1998). [The Draw-A-Person Test. Material in progress]. Test kresby postavy. Pracouný materiál. Prague.

Bakalář, E. (1993). [Methodics 9202. Methodics of examination and assessment for the drivers of motor vehicles by the traffic psychologists]. Metodika 9202. Metodika vyšetrovania a posudzovania vodičov motorových vozidiel dopravnými psychológmi. Bratislava: Asociácia dopravných psychológov.

Carcach, C. \& Leverett, S. (1999). Recidivism among juvenile offenders: An analysis of times to reappearance in court. Australian Institute of Criminology Research and Public Policy Series No. 17, Canberra: Australian Institute of Criminology.

Clark, J. H. (1948). Application of the MMPI in differentiating A.W.O.L. recidivists from non-recidivists. The Journal of Psychology, 26, 229-234.

Coates, R. B. (1981). Deinstituttionalization and the serious juvenile offender: Some policy considerations. Crime \& Delinquency, 4, 477-487.

Dam, C. van, Janssens, J. M. A. M., \& De Bruyn, E. E. J. (2005): PEN, Big Five, juvenile delinquency and criminal recidivism. Personality $\mathcal{E}$ Individual Differences, 1, 7-19.

Dammer, Č. (1995). [The Draw-A-Person Test. Material of the author]. Kresba lidské postavy. Materiál autora. Liptovský Mikuláš: Oddelenie sociálnych služieb Vojenskej akadémie SNP.

Davido, R. (2001). [The drawing as a tool for knowing the child]. Kresba jako nástroj poznání dítěte. Prague: Portál.

Eber, H. W. \& Cattell, R. B. (adapted by Kollárik, T.) (1994). [16 PF - The sixteen factor questionnaire. Form E (T-24)]. 16 PF - šestnástfactorový dotazník. Forma $E(T-24)$. Bratislava: Psychodiagnostika, s.r.o.

Edens, J. F. (2009). Interpersonal characteristics of male criminal offenders: Personality, psychopathological, and behavioral correlates. Psychological Assessment, 1, 89-98.

Freeman, R. A. \& Mason, R. M. (1952). Construction of a key to determine recidivists from non-recidivists using the MMPI. Journal of Clinical Psychology, 2, 207-208.

Fridrich, J. \& Nociar, A. (1991). [The Hand Test. Manual.] Test ruky. Príručka. Bratislava: Psychodiagnostika.

Ganzer, V. J. \& Sarason, I. G. (1973). Variables associated with recidivism among juvenile delinquents. Journal of Consulting and Clinical Psychology, 1, 1-5.

Hanson, R. K. \& Wallace-Carpretta, S. (2004). Predictors of criminal recidivism among male batterers. Psychology, Crime \& Law, 4, 413-427. 
Lee, K. \& Lee, J. (2012). Self-esteem and delinquency in south korean adolescents: Latent growth modeling. School Psychology International, 1, 54-68.

Levy, K. St. C. (1997). Multifactorial self-concept and delinquency in australian adolescents. Journal of Social Psychology, 3, 277-283.

Lobodáš, O. (2000). [The method of treatment of juvenile convicts and their preparation for life in the society]. Spôsob zaobchádzania s mladistvými odsúdenými a ich príprava na život v spoločnosti. In P. ONDREJKOVIČ (Ed.), [The questions of the youth criminality]. Otázky kriminality mládeže (pp. 135-150). Bratislava: Iuventa a MV SR.

Matoušek, O. \& Kroftová, A. (1998). [Youth and delinqency]. Mládež a delikvence. Prague: Portál.

Moffitt, T. E. (1993). Adolescence-limited and life-course-persistent antisocial behavior: A developmental taxonomy. Psychological Review, 4, 674-701.

Moffitt, T. E. \& Caspi, A. (2001). Childhood predictors differentiate life-course persistent and adolescence-limited antisocial pathways among males and females. Development and Psychopathology, 2, 355-375.

Mulder, E., Brand, E., Bullens, R., \& van Marie, H. (2011). Risk factors for overall recidivism and severity of recidivism in serious juvenile offenders. International Journal of Offender Therapy and Comparative Criminology, 55, 118-113.

Raven, J. C., Court, J. H., \& Raven, J. (1991). [Standard progressive matrices $(T-16)]$. Štandardné progresívne matice $(T-16)$. Bratislava: Psychodiagnostika, s.r.o.

Siegel, L. J. \& Senna, J. J. (1998). Juvenile delinquency. Theory, practice and law. New York: West Publishing Company.

Statistical Yearbook 2011. Ministery of Justice of the Slovak Republic [Online], Access: <http://www.justice.gov.sk/stat/roc/12/index.htm > [cit. 2012-11-12]. Šturma, J. \& Vágnerová, M. (1982). [The Draw-A-Person Test (T - 76). Manual]. Kresba postavy $(T-76)$. Príručka. Bratislava: Psychodiagnostické a didaktické testy, n.p.

Tavel, P. (2011). [What about the health of our children?]. Ako je to so zdravím našich detí? Ostium, 2 [Online], Access: <http://www.ostium.sk/index.php? section $=\& \bmod =$ magazine\&act $=$ issue\&id $=31>$ [cit. 2012-11-05] . 